\title{
A Perspective on Nigeria's Preparedness, Response and Challenges to Mitigating the Spread of COVID-19
}

\author{
Madubuike Umunna Anyanwu 1,2@), Ishmael Jaja Festus 2,3,4,*®D, Obichukwu Chisom Nwobi ${ }^{5}$, \\ Chinwe-Juliana Iwu Jaja ${ }^{2,6}\left(\mathbb{D}\right.$ and James Wabwire Oguttu ${ }^{3}(\mathbb{C}$ \\ 1 Microbiology Unit, Department of Veterinary Pathology and Microbiology, University of Nigeria, \\ Nsukka 400001, Nigeria; Madubuike.anyanwu@unn.edu.ng \\ 2 Risk and Vulnerability Science Centre, University of Fort Hare, Alice 5700, South Africa; \\ chinwelolo@gmail.com \\ 3 Department of Livestock and Pasture Science, University of Fort Hare, Alice 5700, South Africa; \\ joguttu@unisa.ac.za \\ 4 Department of Agriculture and Animal Health, University of South Africa, \\ Roodepoort Johannesburg 1710, South Africa \\ 5 Department of Veterinary Public Health and Preventive Medicine, University of Nigeria, \\ Nsukka 400001, Nigeria; obichukwu.nwobi@unn.edu.ng \\ 6 Department of Nursing and Midwifery, Faculty of Medicine and Health Sciences, Stellenbosch University, \\ Cape Town 7505, South Africa \\ * Correspondence: ijaja@ufh.ac.za
}

Received: 29 April 2020; Accepted: 30 June 2020; Published: 21 September 2020

\begin{abstract}
Coronavirus disease 2019 (COVID-19) is a novel disease pandemic that emerged in late 2019 in China, and later spread to other parts of the world, including Nigeria. This review analyzes the preparedness of Nigeria to the COVID-19 pandemic and recommends strategies that could be useful in controlling the disease. Published articles on COVID-19 worldwide, socioeconomic and disease status and preparedness to COVID-19 in Africa and Nigeria, were retrieved from databases such as Pubmed, MEDLINE, Scopus, Web of Knowledge and Google search engine. Nigeria is the most populous black nation in the world, and is one of the largest crude oil producers in the world. However, its healthcare system is dilapidated and weak, due to years of neglect and widespread corruption. As a result, Nigeria is vulnerable to COVID-19, as evidenced by the current geographical distribution of the disease in its population. Many socioeconomic factors could potentially facilitate the spread of COVID-19 in Nigeria. This could lead to a high caseload in the country, which could overwhelm the health care system. The application of social distancing, personal hygiene, especially hand hygiene and mask-wearing, as practiced in many countries, has proven to be effective to reduce the spread of COVID-19. In Nigeria, social distancing, in many instances, may be impracticable, given its large population, and a high density of people living in crowded conditions like slums and camps. Moreover, there is a sizeable population of internally displaced people, due to the attack by Boko Haram fighters in Northern Nigeria, and herdsmen in Southern Nigeria. The implementation of these measures is likely to be a great challenge. Nigeria has announced a complete lockdown for the containment of COVD-19, but its implementation and efficacy are doubtful, due to the same reasons previously mentioned.
\end{abstract}

Keywords: SARS-CoV-2; Boko Haram; health care systems; pandemic; social distancing

\section{Introduction}

More than a decade ago, scientists warned that the high rate of interaction and consumption of wildlife, especially horseshoe bats in China, was a time bomb that could potentially cause the 
reemergence of severe acute respiratory syndrome (SARS) viruses or the emergence of unknown viruses [1]. This warning was unheeded, and consequently, a novel coronavirus, SARS-CoV-2 (formerly $2019 \mathrm{nCoV}$, isolated on 7 January 2020) came to light, causing a contagious respiratory disease, coronavirus disease 2019 (COVID-19, named on 11th February by the WHO).

Coronavirus disease 2019 (COVID-19) is a viral pneumonia with symptoms such as dry cough, fever, sore throat, dyspnea, body pain and diarrhoea [2]. This disease emerged in late December 2019 in Wuhan, in Hubei province of China, and within three months, it had spread globally, prompting the World Health Organization (WHO) to declare COVID-19 a threat to world health [3,4].

SARS-CoV-2 belongs to the family Coronaviridae (of the order Nidovirales, large, positive single-stranded RNA viruses), which are important human and animal viruses, in permanent circulation with four members of this family causing respiratory infections (common cold) worldwide $[5,6]$. Although the SARS (in 2002) and Middle-East respiratory syndrome coronavirus (MERS-CoV) (in 2012) epidemics were not globally dispersed like COVID-19, they seem to have caused more fatalities than COVID-19 [5,7].

As of 14th April 2020, there was a total of 1,978,769 confirmed COVID-19 cases and 125,196 deaths, and cases have been reported in 213 countries, areas or territories [8]. The mortality rate of COVID-19 varies between countries, and the reasons for this variability in mortality are still unclear $[9,10]$. However, in some countries, age has been shown to impact mortality; the older the population, the higher the mortality rate [7]. However, the current figures could be underestimating the morbidity and mortality rate of COVID-19, as it does not take into account asymptomatic patients [11].

Although COVID-19 affects individuals of all ages, greater severity and mortality occur more among the aged population, that have other comorbidities such as hypertension, and other cardiovascular diseases, or diabetes, cancer and other immune-compromising diseases [7]. It has also been observed that COVID-19 seems to affect males more than females [7]. Meanwhile, children tend to exhibit milder symptoms of COVID-19. However, the reason for this is not yet clear $[12,13]$.

The severe form of COVID-19 occurs in three phases-viral, pulmonary and final hyper-inflammatory phase, which can lead to severe acute respiratory distress syndrome (ARDS), impaired cardiac function, and death [12]. Thrombosis and coagulopathy is reported to complicate COVID-19 [14]. Patients suffering from a severe form of COVID-19 often need to be intubated and placed under a ventilator. The chance of survival following SARS-CoV-2 infection for people $\geq 60$ years is $\sim 95 \%$ in the absence of comorbid conditions, but this chance decreases considerably if the patient has underlying health conditions [15].

Because COVID-19 is easily transmitted via droplets and can remain suspended in the air for some hours, transmission can occur through human interactions and contaminated fomites. Travelers from countries with reported cases have enabled the disease to rapidly spread COVID-19 to all continents, including African countries [8]. People residing in Europe (especially from the United Kingdom, France, Germany, Italy, Spain and The Netherlands) and the USA have been categorized as high risk. Hence, travelers from those countries are also regarded as high-risk people [16].

Since COVID-19 spread at a fast rate, individuals from vulnerable health systems and poor socioeconomic backgrounds are particularly at risk [3]. The majority of countries in Sub-Saharan Africa are faced with prolonged health system vulnerabilities due to civil wars, post-military autocratic delayed reforms, corruption, and the emigration of physicians/health workers and other skilled professionals $[17,18]$. Nigeria is a concerning example of a vulnerable health system, and according to the healthcare system corruption rating among Anglophone West African countries by Transparency International, Nigeria ranks the worst [17]. The leadership of the Nigerian Ministry of Health changes with every change in political dispensation, with successive ruling party selecting Health Ministers without consideration of competency. The frequent change of health ministers, coupled with the looting of funds earmarked for the reformation of Nigeria healthcare systems, and government officials often engaging in medical tourism, only serves to make the situation worse [19]. Thus, there is a high burden of chronic diseases such as diabetes mellitus, hypertension, and so on among the population 
of Nigeria, thereby predisposing the majority of them to COVID-19. In its recent history, Nigeria experienced a series of economic crises (in the 1990s, and the first quarter of 2016) due to bad economic policies, corruption and a fall in revenue from crude oil (which forms $80 \%$ of the country's income) due to militancy in oil-producing regions [20]. These, as well as a steadily increasing unemployment rate (5.31\% in 2014 to $6.11 \%$ in 2019) and a high population in Nigeria, forced approximately 5-15 million people to migrate to countries in Europe (Italy, Spain, Germany, United Kingdom, Scandinavia), Asia (China, Malaysia, Middle-East) and North America (USA and Canada) [18,21]. Many of these immigrants have been returning to Nigeria due to the outbreak of COVID-19. This movement of people has resulted in the spread of COVID-19 to and within the country. Due to the potential outrageous impact of COVID-19 pandemic on a population, there is need to understand the preparedness of vulnerable countries in order to devise effective strategies for the mitigation of COVID.

This review describes and analyzes the status of preparedness of Nigeria to COVID-19 and provides recommendations that will be useful to various stakeholders in the country. This also serves the purpose of shared experience amongst countries with similar contexts to Nigeria.

\section{Preparedness of Nigeria to Control COVID-19 Pandemic}

Since Nigeria does not currently have a COVID-19 preparedness plan, we extracted data from a study conducted by Sambala et al. [22], who evaluated the quality of the influenza preparedness plans in the WHO African region. Drawing from the findings of this study, as shown in Figure 1, it is worth noting that Nigeria scored at least $60 \%$ in all of the thematic areas; namely, preparation, coordination and partnership, risk communication, surveillance and monitoring, prevention and containment, case investigation and treatment and ethical considerations. These are the areas in which a country must focus on while preparing for an influenza pandemic. These plans were written in 2007 following advice from the WHO, and it was expected that the countries would have updated these plans, especially after the 2009 pandemic. It is therefore evident that this did not happen further, corroborating the fact that Nigeria was not well prepared for this pandemic. Had Nigeria updated their influenza preparedness plan, perhaps, it would have assisted with the current COVID-19 pandemic.

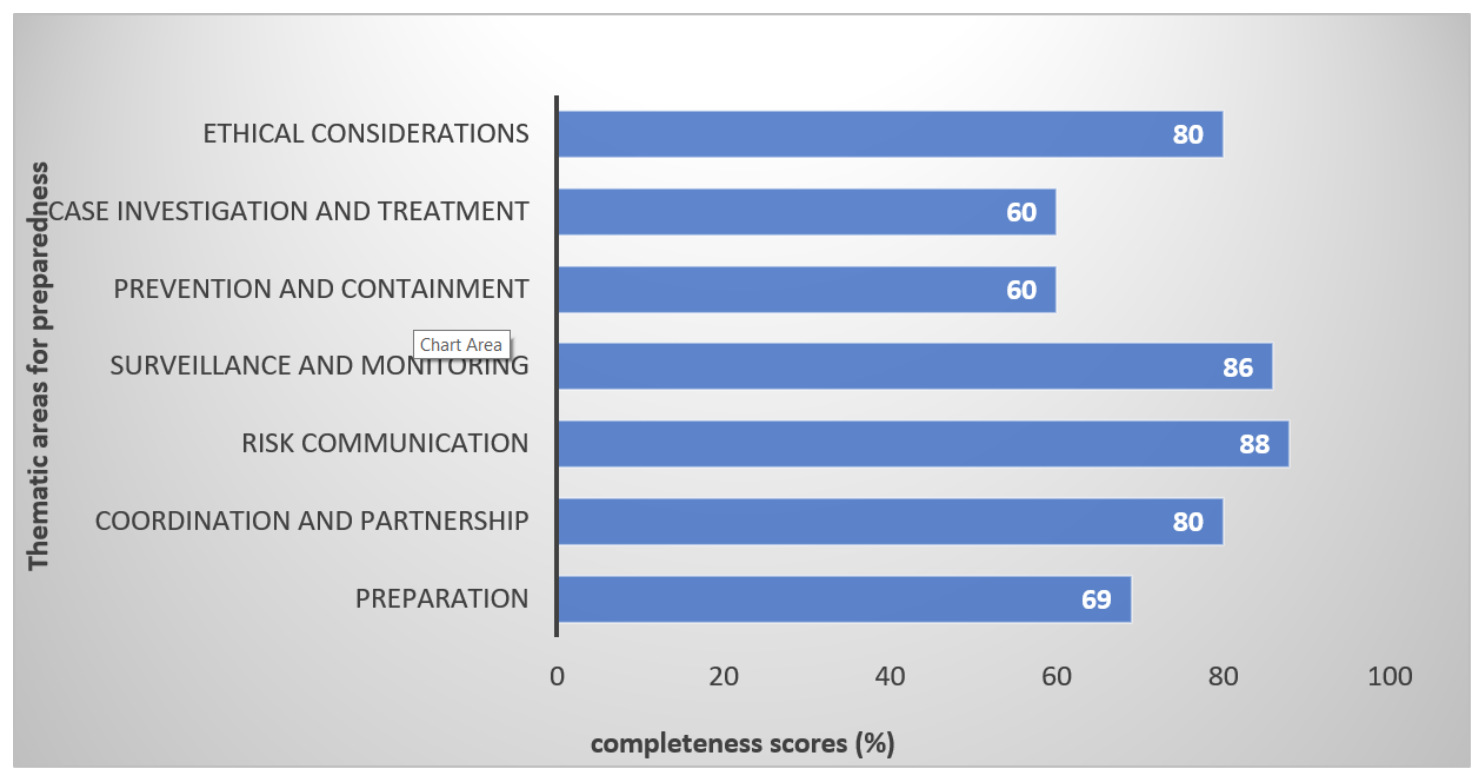

Figure 1. The completeness of Pandemic influenza preparedness plan for Nigeria.

In February 2020, the WHO outlined recommendations (which are updated) for countries to follow in preparation for the response against COVID-19 [23]. Following these recommendations, countries like the UK prepared their preparedness and response plan for COVID-19, further showing how proactive other countries are. Therefore, the question is whether Nigeria has come up with any 
plans since this pandemic, or if they have any contingency plan that is currently being used to respond to COVID-19. We explore the answer to this question in the next section.

\subsection{Risk Communication}

Public awareness among migrant travelers, providing hygiene products and social distancing, are highly suggested to limit the spread of COVID-19 [3,24]. The Nigeria Centre for Disease Control (NCDC), which is responsible for detecting/controlling infectious diseases in Nigeria, created a rather inadequate public awareness for COVID-19 prior to 27th February 2020-the date COVID-19 was first confirmed in Nigeria and the first reported case in Sub-Saharan Africa [25-27]. The index case was an Italian who returned from Italy (an epicenter of COVID-19 in Europe) to Nigeria. After the confirmation of the first COVID-19 case, the NCDC released a set of recommendations and proceeded with the acquisition of medical equipment, with the purpose of the initial identification of travelers arriving with COVID-19 symptoms, especially high fevers at airports, and to trace individuals that had contacts with these travelers [25]. Exposed people were requested to self-isolate and contact the NCDC. The NCDC will, in turn, observed these people for COVID-19 symptoms, collect and ship samples to diagnostic laboratories. These were the suggested measures to control the spread of the disease in the country [26]. However, most travelers/migrants returning to Nigeria from overseas (as well as other African countries) refused to be screened, and provided wrong information about themselves, making it difficult for NCDC to trace them and those that had made contact with them [25]. It is possible that most of these travelers were asymptomatic carriers of SARS-CoV-2, the virus that causes COVID-19 [7]. As a result, the NCDC is not able to account for travelers that pose a serious risk to the public health of the Nigerian population.

There has been a steady rise in the number of COVID-19 cases in Nigeria. As of 14th April 2020, over 5000 exposed people have been tested, 343 tested positive of COVID-19, and 10 deaths have been reported in Nigeria (people with/without underlying conditions). Most of these COVID cases were travelers who had returned to Nigeria from overseas, or those who made direct/indirect contact with them. However, very few of them were as a result of local transmission among people without a travel history from outside of Nigeria, especially from high-risk countries [26]. In view of this, how has Nigeria responded to control and prevented further spread of the contagion? We explore this in the next section of this review report.

\subsection{Surveillance, Diagnosis and Treatment of COVID-19 in Nigeria}

Since SARS-CoV-2 can be carried by a significant number of asymptomatic members of the population, surveillance of COVID-19 using mass testing is recommended as part of the measures to control the spread of the disease $[7,28]$. The use of real-time polymerase chain reaction (RT-PCR) results (using throat swab or other specimens) is the gold standard for diagnosing SARS-CoV-2 [2,29]. However, Nigeria does not currently have adequate facilities for testing its huge population for COVID-19. What is perturbing is that many countries in Sub-Saharan Africa that recorded their index case much later than Nigeria, even with a much smaller population and per capita gross domestic product (GDP), such as Kenya, Gabon, Equatorial Guinea, Uganda and South Africa, have tested more people than Nigeria at the time of writing this paper [27,30]. As of 4th February 2020, Nigeria has already developed the ability to conduct COVID-19 sample testing by itself [31]. Currently, there are only nine centers for testing, and there is a shortage of necessary materials (e.g., test reagents, kits, primers, etc.), coupled with the delay in the delivery of test results. The inadequacy of COVID-19 test materials in Nigeria would potentially cause preferential treatment and bias against the majority of Nigerians from receiving adequate attention regarding the testing and treatment of COVID-19. The situation is not helped by the high potential of false-negative rate of diagnostic of COVID-19 that has already been documented [3].

Appropriate care-seeking behaviour and adherence to public health advice can be sustained in Nigeria if the population has trust in the capacity of the health system to safely meet essential 
needs and control the risk of infection [23]. The maintenance of equitable access to essential service delivery throughout an emergency aimed at limiting mortality directly and avoiding mortality caused by indirect factors is a feature of a well-organized and prepared health system [23].

Early symptoms of COVID-19, including fever, myalgia, and fatigue, might be confused with malaria and lead to challenges in early clinical diagnosis [32]. In view of this, malaria diagnostics should be systematically added to fever management, including for suspected cases of COVID-19 [32]. Moreover, the delay in laboratory test, if diagnosis is based purely on symptoms of fever, may pose the danger of putting a false-positive individual together with COVID-19 patients in isolation. Public-private partnership is crucial to increase the acquisition of health facilities needed to tackle COVID-19 in Nigeria. Encouragingly, Nigeria is among the 13 countries in Africa with close transport links to China that have been prioritized for support with regards to the training of health personnel and funding by the WHO [31].

There is currently no vaccine against COVID-19, but research and clinical trials are ongoing [24], including an investigation of the potential of using convalescent antibodies to treat COVID-19 patients. An appropriate vaccine for COVID-19 is not expected to be available soon, given that COVID-19 is a new disease. Besides, there should be no haste to use a vaccine that has not undergone appropriate clinical trials [33].

Being a new disease, COVID-19 may continue spreading until most people get infected, and herd immunity is developed [34]. However, since asymptomatic carriers of SARS CoV-2 are highly infectious, the societal consequences of achieving herd immunity may be devastating [34]. Moreover, other coronaviruses may also stimulate population immunity in the pharynx of asymptomatic individuals that are not regularly systematically tested around the world [5].

There are currently no therapeutic products shown to be safe and effective for the treatment of COVID-19. However, a number of medicines have been suggested as potential investigational therapies, many of which are now being, or will soon be, studied in clinical trials, including the SOLIDARITY trial co-sponsored by WHO and participating countries [2]. Cocktails of drugs comprising mainly antimalarial, antiviral and antibiotics agents are used in treating COVID-19 worldwide, although there is no valid proof of the efficiency of these drugs $[35,36]$. Fortunately, some of these drugs are available in Nigeria, and since countries such as China, India and those in Europe and the US, from which Nigeria imports most of their drugs, have reported cases of COVID-19, pharmaceutical industries in Nigeria need to scale up production to meet demand when the need arises. There are other agents like Ivermectin available in Nigeria that has also been documented as being promising in the treatment of COVID-19 [2,37].

The basis of managing COVID-19 with cocktails of drugs is because viral infections are ecosystem infections, where the outcomes depend on inoculums and surrounding microbiota, which is often bacterial [5]. This highlights why there is a need for antibiotic stewardship programs in Nigeria to help preserve the efficacy of commonly used antibiotics.

Discharging treated patients merely on the basis of no symptoms or the absence of SARS-CoV-2 in throat swabs only, even with repeated testing, could enhance the spread of COVID-19 in Nigeria, given that SARS-Cov-2 detection in sputum from a patient with COVID-19 has been documented [38]. Therefore, the absence of SARS-CoV-2 nucleic acid in throat swab (upper respiratory) and sputum (lower respiratory) specimens must be ascertained before a patient could be discharged from hospital [38]. This has the potential to avoid continuous discharge of the organism and possible relapse.

\subsection{Response to COVID-19: Containment Plan}

On the of 30th March 2020, the regulation on COVID-19 in Nigeria took effect, putting three of the 36 states (Abuja, Lagos and Ogun) in the country that were deemed the epicenters of COVID-19 on lockdown. However, this was not total lockdown, since some workers are allowed free movement for at least 14 days, in addition to the exemption granted to essential workers. The rationale for a 14-day lockdown was the outcome of a WHO protocol outline that patients would be symptomatic within 
14 days if infected [8]. However, we know that it has been documented that the incubation period for COVID-19 could be as long as 24 days [7]. Another problem with this approach was that, by the end of the 14-day lockdown imposed on only three states in Nigeria, many people in contact with asymptomatic carriers could have contracted COVID-19 [7].

Most workers exempted during the lockdown commuted to their working place in company vehicles without adherence to the social distancing policy. This posed a risk of spreading the disease, since a mass gathering (MG) of any form, including in transport (as exemplified in the Diamond Princess cruise ship) facilitates the spread of COVID-19 [39].

Some facilities in various states were earmarked and turned into isolation centers for COVID-19 patients. However, most of these centers are without basic facilities like adequate water supply and ventilators, and air circulatory systems, which are crucial in the management of COVID-19, especially in critically ill patients [2]. For instance, in Lagos, the Mobolaji Olufunsho Johnson Stadium in Onikan was transformed into a 101-bed isolation center for patients of COVID-19 [40].

Some states in Nigeria also closed their land borders, to try and prevent interstate movement while allowing intrastate transportation. They also prevented gathering in public places like markets, schools, religious centers, and social clubs, in order to reduce human interactions and enhance social distancing. These measures to contain the disease notwithstanding have not been without problems. For example, in Rivers state, the police arrested and prosecuted two pilots of Caverton Helicopters for transporting 220 passengers to the state capital (Port Harcourt) without approval. Similarly, pastors, in many parts of Nigeria, have been arrested or warned for holding church services [41].

\subsection{Impact of COVID-19 on the Social Determinants of Health}

The lockdown (also known as sit/stay at home policy) policy will impact negatively on the majority of people in Nigeria who feed and survive only by what they earn daily. The situation will be worse, owing to little or no social welfare packages or palliative assistance provided by the government for the most vulnerable people in society. Moreover, lack of payment of salaries by state governments, increase in the price of commodities/foods and tariffs on inadequately supplied utilities like electricity are some factors that will make the lockdown unbearable.

The impact of the lockdown on the wellbeing of communities through economic recession or job losses should not be overlooked [42]. Restricting the movement of people may impact on their psychological wellbeing $[43,44]$. School closures will impede learning disproportionately in children from disadvantaged communities, leading to teenage pregnancy and gender-based violence in homes [45]. Hence, the WHO has outlined guidelines that need to be taken into consideration before cancelling MG, as the measure could be counterproductive in the long run [42].

While Nigeria took the right decision in shutting down states that constituted epicenters of COVID-19, and closing of borders in some states in its effort to curb the interstate spread of COVID-19, of concern is the people who live in slums/internally displaced people's camps, who often suffer from malnutrition, various non-communicable diseases and infectious diseases (including HIV/AIDS) and tuberculosis. These are the populations that are at a greater risk of COVID-19 [45]. Unfortunately, an estimated 1.9 million people are living with HIV in Nigeria, with $1.4 \%$ of these among Nigeria's youthful adults aged 15-49 years [46], while a latest report showed that incidence of tuberculosis rose in Nigeria from 418,000 cases in 2017 to 429,000 cases in 2018, with tuberculosis treatment coverage stagnant at $24 \%$ [47]. Data from other respiratory diseases, including pneumococcal pneumonia and pulmonary tuberculosis, showed that people living with HIV (PLHIV) with compromised immunity have significantly worse health outcomes [48-50]. Based on this, people living with HIV with low CD4+ T-cell count or not on antiretroviral therapy (ART) are potentially vulnerable to a more severe form of the COVID-19 disease [49]. Nevertheless, previous coronavirus outbreaks, including SARS CoV-1 and MERS, were limited among PLHIV, giving a glimmer of hope that PLHIV in Nigeria may not have a significantly higher risk of infection or mortality from SARS-CoV-2 [49]. 
A typical example of this scenario is Borno state, a place that has suffered from years of terrorist attacks, leading to the death and displacements of many people. Currently, there are about 1.5 million internally displaced people (IDP). Most of these displaced people live in overcrowded camps with poor water and sanitation facilities, limited supplies of hygiene essentials such as soap and water, and often no individual space at all. For this category of people, social distancing and other precautionary measures are not feasible without humanitarian assistance [51].

Furthermore, despite good intentions, the response to COVID-19 in Nigeria may come at the expense of treating other diseases. For example, in the Democratic Republic of Congo, the response to Ebola resulted in the resurgence of measles [45]. Currently, less attention is being given to Lassa fever, which is rapidly increasing in Nigeria [52]. Individuals suffering from other illnesses may avoid seeking hospital treatment for fear of being infected by SARS-CoV-2 infection [53]. The impact of school closures and the lockdown in Nigeria, especially on children and their parents, may be unquantifiable, and debate on this is ongoing worldwide [45]. UNICEF has warned that the impact of the policy of lockdown/school closure has far-reaching consequences than just the loss of education [45]. This is with reference to the school feeding programs that benefit millions of children. The UN Food and Agriculture Organization (FAO) assessed that these programs constitute one of the most reliable daily sources of food for millions of children [54]. Most children, especially in northern Nigeria, depend on a school food program for their daily food, so with this school closure, these children are at great risk of malnutrition.

Most parents in Nigeria have informal and casual jobs and are not able to work from home, thus potentially making their children more vulnerable to malnutrition [45]. Sudden loss of income or access to social support could have consequences that are difficult to estimate, and these constitute a challenge in identifying all those who might become vulnerable [45]. As in the case of Ebola in parts of Africa, where there have been outbreaks, there are also increased risks of pregnancy in young girls, school dropout, and child abuse [45].

Because of weak institutions in Nigeria, the lockdown/quarantines could potentially spark violence and tension between citizens and political parties, with the possibility of even extrajudicial killings [55]. The Nigerian government must respond to the lockdown swiftly, by supplying money, food, drugs and material reliefs to these vulnerable groups [32,54]. Funds/foods/materials provided as a palliative in an emergency should not be given as loans to vulnerable people, and bureaucratic bottlenecks should be removed to enable these people to have easy access to services.

Nigeria has begun to distribute national identification numbers and cards to its citizens; however, less than $20 \%$ of citizens have this identification system. The lack of a national database of citizens in Nigeria and corruption can hamper the equitable distribution of assistance provided by the government, especially to the most vulnerable in society. Although the effects of the lockdown in Nigeria seem to be impacting people who depend on daily income, for now, the dynamics of vulnerability could change, and a person not considered vulnerable at the outset of a pandemic can become vulnerable depending on the policy response [45].

\section{Socio-Economic and Political Challenges That May Hamper the Control of COVID-19 Spread in Nigeria}

Nigeria is a diverse country with an estimated population $>205$ million, with the majority $(69 \%$ in 2019,87 million people in 2018) living (on $<\$ 1$ a day) in abject poverty, and without access to basic amenities (shelter, clean water, health care, etc.). This is despite it being one of the largest crude oil producers in the world [56]. Since the majority of people in Nigeria are poor, adherence to the lockdown would be difficult, even with enforcement, because these people need daily income to sustain themselves. In addition, an estimated $\sim 65-75$ million Nigerians are illiterate [57], and are thus vulnerable to wrong information, even about COVID-19. This can hinder the population from appreciating the potentially devastating impact the pandemic could have on the population at large. Apart from investors pulling out their investments from Nigeria's stock markets due to uncertainties, 
Nigeria's economic mainstay, which is crude oil, plunged, due to a lack of buyers, which could potentially result in an economic recession. The high COVID-19 case fatality rate among the aged population in Nigeria could diminish a generation endowed with knowledge that should be transferred to younger generations. The psychosocial effect of COVID-19 fatality on health workers and the general population is immeasurable. However, the median age of the Nigerian population is 18.1 years, with an estimated half of its population under 30 years of age, suggesting that the case fatality of COVID-19 in Nigeria may not be outrageously high.

The prolonged fight against terrorism (since 2009, but has escalated in 2014 up to now) and banditry activities prevalent in the northern part of Nigeria [56] have the potential to distract the government's attention from COVID-19.

An estimated $>2.5$ million children and $7 \%$ of women of child-bearing age in Nigeria are suffering severe acute malnutrition [58]. The adequate function of the immune system is critical in viral diseases. Immune cells ( $\mathrm{T}$ and B cells) constitute proteins made up of amino acids, and dietary microelements such as selenium and zinc are critical for the production of proteins. Arginine is an amino acid which is essential for the generation of nitric oxide by macrophages, and micronutrients vitamin A and zinc regulate cell division, and so are critical for a successful proliferative response within the immune system. Breast milk is rich in bifidogenic oligosaccharides and contains its own unique microbiota, so breastfeeding is important in providing passive immunity to the infants. Cellular demand for energy is increased during periods of infection, and in fever (as in SARS CoV-2), there is greater basal energy expenditure. Therefore, the optimal nutrition for the malnourished in Nigeria during the COVID-19 pandemic should be nutrition which supports the functions of immune cells to allow them to initiate an effective response against pathogens, and to rapidly resolve the response when necessary, in order to avoid any underlying chronic inflammation [59]. However, starvation and malnutrition/undernutrition negatively affect the immune system and could reduce the chances of victims surviving COVID-19, especially children, women and the aged [60]. Moreover, COVID-19 affects pregnant women, and the vertical transmission of SARS-CoV-2 to the unborn fetus has already been documented [61,62].

An estimated $\sim 80$ million people in Nigeria live in slums, in very unhygienic and unsanitary conditions (without basic amenities like potable water and toilet systems) [63], and in these slums, avoidance of human interactions (since they live in close proximity) and social distancing is practically impossible. An estimated $\sim 2.5$ million people are internally displaced (ID) by the activities of terrorists in northern Nigeria, and these people are crowded in unsanitary camps, where hygiene and social distancing is practically impossible [64]. Viruses can persist in feces long after they are absent from nasopharyngeal secretions and the recovery of SARS-CoV-2 from the stool of a person with confirmed COVID-19 has already been documented $[12,65,66]$. So, the fecal-oral transmission of COVID-19 may be possible [8]. An estimated $\sim 47$ million in Nigeria practice open defecation, especially in slums as well as in urban areas [67]. These conditions are conducive for an upsurge in spread of SARS-CoV-2 among populations living in unsanitary environments.

We know that hygiene is recommended to prevent the transmission of COVID-19, but for this to be effective, potable water is necessary (WHO, 2020). However, an estimated 100 million Nigerians still lack basic sanitation facilities, and 63 million do not have access to potable water [68]. This renders the attempt to contain COVID-19 in Nigeria a near-impossible task.

The statutory retirement age in Nigeria is 60 years or 35 years of unbroken service [69]. Retired civil servants in Nigeria are entitled to benefits such as gratuity and pensions. However, for some years, the Nigerian government (especially the state governments) has not managed to pay these entitlements to this group of people, either entirely or on time [70]. This group of pensioners may thus be among the malnourished in the population, and with comorbidities such as diabetes mellitus and hypertension. It is actually estimated that $\sim 62$ million Nigerians are hypertensive [71], while $\sim 11$ million have diabetes mellitus [72]. Individuals with these chronic diseases are potentially vulnerable to COVID-19, since these conditions are associated with the decreased functions (chemotaxis, phagocytosis and killing) of polymorphonuclear cells and monocytes/macrophages [73-75]. Moreover, the available 
evidence suggests that aged people (especially $\geq 80$ years) are much more vulnerable to the severe form of COVID-19 [15,76]. This notwithstanding, there is virtually no nursing homes where the older people are cared for in Nigeria. So, they live with their children/caretakers that could quickly transfer the diseases, including COVID-19.

\section{Religion, Border Control, and National Approach}

In some states, a total lockdown has been enforced, whereas elsewhere, government agencies' and NGOs' distribution of relief materials (including hand hygiene reagents and masks) lead to MG, which potentially facilitates the spread of COVID-19 [39]. It is also important to highlight that Nigeria is a deeply religious country and politicians often use religion as a tool to govern. For instance, Akwa Ibom, Rivers and Kastina states in Nigeria approved mass gatherings (MG) for religious activities on Easter weekend and did not consider the transmissibility of COVID-19 when a large crowd gathered for one church service. The following statement was issued by the Rivers state governor just before Easter:

In the Spirit of Easter, therefore, and after a careful review of the state of COVID 19 situation in our State, we have decided to temporarily relax the restriction on large religious gathering, as follows: Friday 10th April 2020-all Moslem faithful should observe Juma'at prayers in their mosques or prayer grounds throughout the State and pray for the peace, forgiveness and the blessings of Allah upon the State. "Sunday 12th April 2020-all Christians should have Easter Church Services with their full congregation and pray to God to forgive us of our sins, continue to intervene in our affairs and protect the State and our people from the Coronavirus. [77]

Religious sentiments by leaders such as those expressed above can reverse any gain of the lockdown. In southern Nigeria, border control measures are tightly in place; however, in northern Nigeria, it is challenging to restrict movement across the border. The governors of northern states raised concerns that enforcing cross-border movements remains a challenge, as some of the COVID cases recorded in their states were imported from other states, despite the closure of borders by their respective governments. These governors further regretted that, so far, no state in the region has received federal funds allocated for the provision of palliative measures during the lockdown. At the time of writing this paper, there is not a single testing center in northern Nigeria [78].

Even though Nigeria has a federal constitution, with states and local governments sharing equal power as federating units, efforts by the federal government to operate a national control center have mostly been hampered by states issuing directives which contradict those of the federal government. For example, the Kwara state government approved that markets can open for trade on Mondays, Wednesdays and Fridays during the total lockdown [79]. Other states in the federal have, at one point or another, relaxed the total lockdown to allow for the movement of people and food. The mass gathering of people characterizes markets in Nigeria in such a manner that social distancing is impossible. The lack of a national approach to the lockdown and the indiscriminate suspension and renewal of lockdown in various states in Nigeria imperil the control of COVID-19.

\section{Projected Future COVID-19 Scenario in Nigeria and Recommendations}

In light of the previous discussion on the challenges of combating COVID-19, the number of COVID-19 confirmed cases that have been reported in Nigeria at the time of writing is likely an underestimation. Therefore, the number of COVID-19 cases in the country may increase, even as imported cases decline and local transmission among those without travel history increases. High caseloads in Nigeria may lead to a reduced health workforce following the infection of health workers. Health workers are at greater risk of contracting the infection because of the close contact with COVID-19 patients (whom they intubate, treat, examine, feed etc.), and in addition, they are potential vehicles for spreading the virus to the general public [1]. Because SARS-CoV-2 is transmitted through diverse routes, including nasal, ocular and oral, health workers in Nigeria need personnel 
protective equipment (PPE) that can cover the entire face and body, in order to reduce the risk of being infected with COVID-19 $[2,6,80]$. Precaution should be taken by health workers in Nigeria in selecting, putting on and disposing of PPE, including masks (for specific procedures such as N95 and FFP2), goggles/face shields, gloves, gowns and aprons, in order to avoid contamination. Shortages of PPE, especially the recommended N95/FFP2 masks in Nigerian hospitals, have now been worsened by the global closure of factories, especially in China, meaning that health workers in Nigeria should improvise PPE in order to protect themselves. The submarine Easybreath Decathlon mask, which has the advantage of being high sealing covering the entire face, easily cleaned, disinfected, sterilizable, durable (not disposable) and relatively cheap, has been suggested as an effective substitute for the N95/FFP2 masks for health workers in Africa [81].

Nigeria needs to scale up its testing capacity in order to effectively monitor the effectiveness of non-pharmaceutical interventions and exercise flexibility in its implementation needs, which should be guided by the surveillance of the community transmission of SARS CoV-2. The pooling of samples and the acquisition of advanced technological sample testing machines like the Xpert Xpress SARS-CoV-2 (since there are trained personnel for the GeneXpert modules used for tuberculosis) are ways to scale up surveillance of SARS CoV-2 [52]. Because TB and COVID-19 may present similar symptoms, clinicians in Nigeria should cautiously endeavor to collect proper clinical history that may enable them to distinguish one from the other [53].

SARS-CoV-2 can remain suspended in the air for a couple of hours [82]. Therefore, the use of fans/air conditioning in hospitals in Nigeria during this pandemic should be done with caution. If any form of air conditioning is to be implemented, it must involve the creation of negative pressure in the wards or hospitals [2]. The disinfection of hospital equipment and the environment, especially places frequently touched by people (such as door knobs, rail handles, etc.) is critical for the control of COVID-19. This is because SARS-CoV-2 can survive for a couple of days on all inanimate objects, irrespective of their nature (be it plastic, metal, cloths or paper). Fortunately, the exposure time for different materials has now been documented [83]. Therefore, care must be taken to prevent the healthcare systems in Nigeria being overwhelmed by COVID-19, because both direct mortality from an outbreak of COVID-19, and indirect mortality from vaccine-preventable and treatable conditions, could increase dramatically when health systems are overwhelmed [84]. Since PLHIV and tuberculosis are potentially at high risk of COVID-19, it will be important that Nigeria does not suspend the HIV 90-90-90 efforts during the SARS CoV-2 pandemic, but rather, it should strive to expand ART, in order to protect PLHIV from severe COVID-19 disease. ART may improve immune response in PLHIV, thereby helping to impede cytokine release syndrome or the progression of SARS CoV-2 infection to severe respiratory failure. Integrating COVID-19 testing services within the HIV and tuberculosis treatment infrastructure could be essential for controlling the spread of SARS-CoV-2 in Nigeria [49]. Diets enriched with vitamins/minerals are important, especially for those vulnerable to COVID-19, such as diabetics, hypertensives, breastfeeding women and infants, in order to boost their immune response. It is also important that Nigeria does not suspend its routine immunization, especially for vitamin $\mathrm{A}$, tuberculosis and poliomyelitis.

Public awareness, widespread public health measures, and close collaboration with countries from which travelers are leaving to Nigeria is key to limiting the spread of COVID-19 in the country, promoting the wellbeing of travelers and the population at large [3]. The rapid testing of travelers returning from countries regarded as the epicenters of the virus and using test results as a basis to inform decisions on who to quarantine has proven to be effective in preventing the spread of COVID-19 [85]. This is important because humans can be irrational in quite a systematic way when it comes to making decisions that involve risks and anxiety. Moreover, the perception of COIVD-19 as a death-sentence has created a stigma around the disease. This stigmatization is not far-fetched and is often enhanced by the media that tends to distort how a new disease is perceived [36].

In case the number of COVID-19 cases in Nigeria continues rising, there may be a need for strategic shifts, to ensure that increasingly limited resources are utilized to provide maximum benefit for the 
Nigerian population [84]. The fear factor related to death from COVID-19 has been documented [86]; hence, authorities in Nigeria should take advantage of this, and utilize the media to educate the population about the disease, and douse their fears, especially as the cases continue to increase.

Key things to know about COVID-19 are that: (i) most people who will get infected by SARS-CoV-2 will most probably experience mild to moderate respiratory illness that will likely resolve without any special treatment [4,24]; (ii) though the fatality rate is low for younger people, COVID-19 is not just like influenza, and once a young person is infected with SARS-CoV-2, the mortality rate is three times higher than that of seasonal influenza [15]; (iii) children suffer a milder form of COVID-19, but they should be prevented from getting COVID-19, because it does cause the death of children in all age ranges [7]; (iv) children carry large amounts of viruses without showing signs, so they could potentially transmit SARS-CoV-2 to other age groups [12]; and (v), although the WHO recommends mask to be worn only by those who are sick or taking care of COVID-19 patients, mask-wearing (even if its cloth/cotton mask) will trap droplets from the mouth/nose, preventing the virus from being released, thereby reducing the spread of COVID-19 $[9,10]$. In view of this, a policy for the general public to wear masks should be considered immediately, since a significant part of the infected population are asymptomatic carriers, but can release SARS-CoV-2 into the environment [7,32].

\section{Concluding Remark}

It is evident that Nigeria was not as well prepared for the COVID-19 outbreak as at the time when the first case was recorded, and thus the response was inadequate. With a dilapidated health care system and the poor socioeconomic status of most its population, Nigeria is vulnerable to the disastrous effects of COVID-19. While the effective implementation of measures like social distancing, hand hygiene and mask-wearing has the potential to curtail the spread of COVID-19 in Nigeria, a total lockdown is likely to have unintended consequences. It should, as a result, be implemented with utmost care. Since no same strategy seems to be working for all the countries, Nigeria need to develop strategies that are suitable to control COVID without causing a detrimental/unwarranted impact on its population. Most people in Nigeria who contract SARS-CoV-2 are likely to experience mild to moderate respiratory illness that will likely resolve with little or no treatment. Because Nigeria has mostly a youthful population, there is a glimmer of hope that the case fatality rate of COVID-19 in Nigeria may not be outrageously high, as has occurred in COVID epicenters elsewhere. COVID-19 may continue spreading until most people get infected, and the general population develops herd immunity, but it may come with serious consequences. It is also possible that population immunity may be stimulated by other coronaviruses that have rarely been tested around the world, but are inhabitant in the pharynx of asymptomatic people. Potential bias on issues raised about preparedness, especially with regards to communication in this study, could arise, since there was no consultation of the government authorities. Moreover, bias on the knowledge about potential impact of a pandemic raised in this study may emanate, since the awareness/perceptions of Nigerians was not assessed. The government of Nigeria should view preparedness as a crucial investment, because its cost is small compared with the unmitigated impact of a resultant health emergency that would occur if the health system was to become overwhelmed.

Author Contributions: Conceptualization, M.U.A., I.J.F., O.C.N., C.-J.I.J. and J.W.O.; methodology, M.U.A., I.J.F., C.-J.I.J.; validation, I.J.F. and C.-J.I.J.; formal analysis, C.-J.I.J.; resources, M.U.A., I.J.F., C.-J.I.J.; data curation, C.-J.I.J.; writing—original draft preparation, M.U.A., C.-J.I.J.; writing—review and editing, M.U.A., I.J.F., C.-J.I.J., J.W.O. All authors have read and agreed to the published version of the manuscript.

Funding: This research received no external funding.

Conflicts of Interest: The authors declare no conflict of interest. 


\section{References}

1. Cheng, V.C.C.; Lau, S.K.P.; Woo, P.C.Y.; Kwok, Y.Y. Severe acute respiratory syndrome coronavirus as an agent of emerging and reemerging infection. Clin. Microbiol. Rev. 2007, 20, 660-694. [CrossRef] [PubMed]

2. Adhikari, S.P.; Meng, S.; Wu, Y.-J.; Mao, Y.-P.; Ye, R.-X.; Wang, Q.-Z.; Sun, C.; Sylvia, S.; Rozelle, S.; Raat, H.; et al. Epidemiology, causes, clinical manifestation and diagnosis, prevention and control of coronavirus disease (COVID-19) during the early outbreak period: A scoping review. Infect. Dis. Poverty 2020, 9, 29. [CrossRef] [PubMed]

3. Gherghel, I.; Bulai, M. Is Romania ready to face the novel coronavirus (COVID-19) outbreak? The role of incoming travelers and that of Romanian diaspora. Travel Med. Infect. Dis. 2020, 101628. [CrossRef] [PubMed]

4. Sohrabi, C.; Alsafi, Z.; O’Neill, N.; Khan, M.; Kerwan, A.; Al-Jabir, A.; Iosifidis, C.; Agha, R. World Health Organization declares global emergency: A review of the 2019 novel coronavirus (COVID-19). Int. J. Surg. 2020, 76, 71-76. [CrossRef]

5. Roussel, Y.; Giraud-Gatineau, A.; Jimeno, M.-T.; Rolain, J.-M.; Zandotti, C.; Colson, P.; Raoult, D. SARS-CoV-2: Fear versus data. Int. J. Antimicrob. Agents 2020, 105947. [CrossRef]

6. Peng, X.; Xu, X.; Li, Y.; Cheng, L.; Zhou, X.; Ren, B. Transmission routes of 2019-nCoV and controls in dental practice. Int. J. Oral Sci. 2020, 12. [CrossRef]

7. Lai, C.-C.; Liu, Y.H.; Wang, C.-Y.; Wang, Y.-H.; Hsueh, S.-C.; Yen, M.-Y.; Ko, W.-C.; Hsueh, P.-R. Asymptomatic carrier state, acute respiratory disease, and pneumonia due to severe acute respiratory syndrome coronavirus 2 (SARSCoV-2): Facts and myths. J. Microbiol. Immunol. Infect. 2020, 1-36. [CrossRef]

8. WHO. Coronavirus Disease 2019. Available online: https://www.who.int/emergencies/diseases/novelcoronavirus-2019 (accessed on 25 April 2020).

9. CNN. Should You Wear a Mask? US Health Officials Re-Examine Guidance Amid Coronavirus Crisis. Available online: https:/edition.cnn.com/2020/03/31/health/coronavirus-masks-experts-debate/index.html (accessed on 4 April 2020).

10. Leung, N.H.L.; Chu, D.K.W.; Shiu, E.Y.C.; Chan, K.-H.; Mcdevitt, J.J.; Hau, B.J.P.; Yen, H.-L.; Li, Y.; Ip, D.K.M.; Peiris, J.S.M.; et al. Respiratory virus shedding in exhaled breath and efficacy of face masks. Nat. Med. 2020. [CrossRef]

11. Baud, D.; Qi, X.; Nielsen-Saines, K.; Musso, D.; Pomar, L.; Favre, G. Real estimates of mortality following COVID-19 infection. Lancet Infect. Dis. 2020. [CrossRef]

12. Brodin, P. Why is COVID-19 so mild in children? Acta Paediatr. 2020. [CrossRef]

13. Okyay, R.A.; Sahin, A.R.; Aguinada, R.A.; Tasdogan, A.M. Why are Children Less Affected by COVID-19? Could there be an Overlooked Bacterial Co-Infection? Eurasian J. Med. Oncol. 2020, 4, 104-105. [CrossRef]

14. Carsana, L.; Sonzogni, A.; Nasr, A.; Rossi, R.S.; Pellegrinelli, A.; Zerbi, P.; Rech, R.; Colombo, R.; Antinori, S.; Corbellino, M.; et al. Pulmonary post-mortem findings in a series of COVID-19 cases from northern Italy: A two-centre descriptive study. Lancet Infect. Dis. 2020. [CrossRef]

15. Ruan, S. Likelihood of survival of coronavirus disease 2019. Lancet Infect. Dis. 2020. [CrossRef]

16. Pullano, G.; Pinotti, F.; Valdano, E.; Boëlle, P.-Y.; Poletto, C.; Colizza, V. Novel coronavirus (2019-nCoV) early-stage importation risk to Europe, January 2020. Eurosurveillance 2020, 25. [CrossRef]

17. Onwujekwe, O.; Agwu, P.; Orjiakor, C.; Mckee, M.; Hutchinson, E.; Mbachu, C.; Odii, A.; Ogbozor, P.; Obi, U.; Ichoku, H.; et al. Corruption in Anglophone West Africa health systems: A systematic review of its different variants and the factors that sustain them. Health Policy Plan. 2019, 34, 529-543. [CrossRef]

18. Olu-Owolabi, E.F.; Wogu, I.A.P.; Azogu, A.F.; Emmanuel, H.O.; Ezeji, A.; Misra, S.; Ogbuehi, U.K. The Mass Media, Migration Issues, and the Brain Drain. Nexus: Implications for Political Development in 21st Century Nigeria. In Handbook of Research on the Global Impact of Media on Migration Issues, 1st ed.; IGI Global: Hershey, PA, USA, 2020; ISBN 9781799802105.

19. Adeloye, D.; David, R.A.; Olaogun, A.A.; Auta, A.; Adesokan, A.; Gadanya, M.; Kehinde Opele, J.; Owagbemi, O.; Iseolorunkanmi, A. Health workforce and governance: The crisis in Nigeria. Hum. Resour. Health 2017, 15, 32. [CrossRef]

20. Ibrahim, A.S.; Lanhui, W.; Habibi, S.M.-G. An Analysis on the Causes and Effects of Recent Economic Recession on the Nigerian Economy. J. Soc. Sci. Humanit. 2018, 6, 453-463. 
21. Darkwah, S.A.; Verter, N. Determinants of international migration: The nigerian experience. Acta Univ. Agric. Silvic. Mendelianae Brun. 2014, 62, 321-327. [CrossRef]

22. Sambala, E.Z.; Kanyenda, T.; Iwu, C.J.; Declan Iwu, C.; Jaca, A.; Wiysonge, C.S. Pandemic influenza preparedness in the WHO African region: Are we ready yet? BMC Infect. Dis. 2018, 18, 567. [CrossRef]

23. World Health Organization. 2019 Novel Coronavirus (2019-nCoV): Strategic Preparedness and Response Plan; World Health Organization: Geneva, Switzerland, 2020.

24. WHO. Coronavirus. Available online: https://www.afro.who.int/news/volunteering-nigerias-covid-19-battle (accessed on 25 June 2020).

25. Adepoju, P. Nigeria Responds to COVID-19; First Case Detected in Sub-Saharan Africa. Available online: https://www.nature.com/articles/d41591-020-00004-2 (accessed on 25 April 2020).

26. NCDC. NCDC Coronavirus (COVID-19). Available online: https://covid19.ncdc.gov.ng/ (accessed on 25 April 2020).

27. Anjorin, A. The coronavirus disease 2019 (COVID-19) pandemic: A review and an update on cases in Africa. Asian Pac. J. Trop. Med. 2020, 13, 199. [CrossRef]

28. WHO. Laboratory Testing Strategy Recommendations for COVID-19; World Health Organization: Geneva, Switzerland, 2020.

29. Huang, Y.; Cheng, W.; Zhao, N.; Qu, H.; Tian, J. CT screening for early diagnosis of SARS-CoV-2 infection. Lancet. Infect. Dis. 2020. [CrossRef]

30. Bougherara, H.; Benramache, S. The effect of the equator on the total coronavirus cases in nine countries from Africa. J. Clin. Exp. Investig. 2017, 11, em00747. [CrossRef]

31. Makoni, M. Africa prepares for coronavirus. Lancet 2020, 395. [CrossRef]

32. Wang, J.; Xu, C.; Kwan Wong, Y.; He, Y.; Adegnika, A.A.; Kremsner, P.G.; Agnandji, S.T.; Sall, A.A.; Liang, Z.; Qiu, C.; et al. Preparedness is essential for malaria-endemic regions during the COVID-19 pandemic. Lancet 2020. [CrossRef]

33. Stratton, K.; Ford, A.; Rusch, E.; Clayton, E.W. Adverse Effects of Vaccines: Evidence and Causality, 1st ed.; National Academies Press: Washington, DC, USA, 2012; ISBN 0309214351.

34. Randolph, H.E.; Barreiro, L.B. Herd Immunity: Understanding COVID-19. Immunity 2020, 52, 737-741. [CrossRef]

35. Baron, S.A.; Devaux, C.; Colson, P.; Raoult, D.; Rolain, J.-M. Teicoplanin: An alternative drug for the treatment of coronavirus COVID-19? Int. J. Antimicrob. Agents 2020, 18, 1. [CrossRef]

36. Gautret, P.; Lagier, J.-C.; Parola, P.; Hoang, V.T.; Meddeb, L.; Mailhe, M.; Doudier, B.; Courjon, J.; Giordanengo, V.; Vieira, V.E.; et al. Hydroxychloroquine and azithromycin as a treatment of COVID-19: Results of an open-label non-randomized clinical trial. Int. J. Antimicrob. Agents 2020, 105949. [CrossRef]

37. Caly, L.; Druce, J.D.; Catton, M.G.; Jans, D.A.; Wagstaff, K.M. The FDA-approved Drug Ivermectin inhibits the replication of SARS-CoV-2 In Vitro. Antiviral Res. 2020, 104787. [CrossRef]

38. Zhu, N.; Zhang, D.; Wang, W.; Li, X.; Yang, B.; Song, J.; Zhao, X.; Huang, B.; Shi, W.; Lu, R.; et al. Positive result of Sars-Cov-2 in sputum from a cured patient with COVID-19. N. Engl. J. Med. 2020, 727-733. [CrossRef]

39. Ebrahim, S.H.; Memish, Z.A. COVID-19—the role of mass gatherings. Travel Med. Infect. Dis. 2020. [CrossRef]

40. CRTV COVID-19: Lagos National Stadium Transformed into a101-bed Isolation Centre 2020, 5. Available online: http://www.crtv.cm/2020/03/covid-19-lagos-national-stadium-transformed-into-a101-bed-isolationcentre/ (accessed on 25 April 2020).

41. PUNCH Caverton flew in 220 passengers without COVID-19 screening-Rivers-Punch Newspapers. Available online: https:/punchng.com/caverton-flew-in-220-passengers-without-covid-19-screening-rivers/ (accessed on 25 April 2020).

42. Nkengasong, J.N.; Mankoula, W. Looming threat of COVID-19 infection in Africa: Act collectively, and fast. Lancet 2020. [CrossRef]

43. El Zowalaty, M.E.; Järhult, J.D. From SARS to COVID-19: A previously unknown SARS-CoV-2 virus of pandemic potential infecting humans-Call for a One Health approach. One Health 2020, 9, 100124. [CrossRef] [PubMed]

44. Al-Rabiaah, A.; Temsah, M.H.; Al-Eyadhy, A.A.; Hasan, G.M.; Al-Zamil, F.; Al-Subaie, S.; Alsohime, F.; Jamal, A.; Alhaboob, A.; Al-Saadi, B.; et al. Middle East Respiratory Syndrome-Corona Virus (MERS-CoV) associated stress among medical students at a university teaching hospital in Saudi Arabia. J. Infect. Public Health 2020. [CrossRef] [PubMed] 
45. Armitage, R.; Nellums, L.B. Considering inequalities in the school closure response to COVID-19. Lancet Glob. Heal. 2020, 20. [CrossRef]

46. UNAIDS. 2030-Ending the AIDS Epidemic; UNAIDS: Geneva, Switzerland, 2019; Available online: https: //www.unaids.org/sites/default/files/20190314_PR_Nigeria_en.pdf (accessed on 25 April 2020).

47. Adepoju, P. Nigeria's widening tuberculosis gap. Lancet 2020. [CrossRef]

48. Lawn, S.D.; Myer, L.; Edwards, D.; Bekker, L.-G.; Wood, R. Short-term and long-term risk of tuberculosis associated with CD4 cell recovery during antiretroviral therapy in South Africa. AIDS 2009, 23, 1717-1725. [CrossRef]

49. Drain, P.K.; Garrett, N. SARS-CoV-2 pandemic expanding in sub-Saharan Africa: Considerations for COVID-19 in people living with HIV. EClinicalMedicine 2020. [CrossRef]

50. Obert, R.; Irschtick, E.H.; Effrey, J.; Lassroth, G.; Ordan, A.C.J.; Ilcosky, I.C.W.; Eanne, J.; Allace, M.W.; Vale, A.A.K.; Orman, N.; et al. Bacterial pneumonia in persons infected with the Human Immunodeficiency Virus. N. Engl. J. Med. 1995, 333, 845-851.

51. MSF. Diseases will persist during COVID-19 in Borno Nigeria. MSF. Available online: https://www.msf.org/ borno-state-diseases-will-persist-during-covid-19-pandemic (accessed on 13 April 2020).

52. Senghore, M.; Savi, M.K.; Gnangnon, B.; Hanage, W.P.; Okeke, I.N. Leveraging Africa's preparedness towards the next phase of the COVID-19 pandemic. Lancet Glob. Health 2020, 8, e884-e885. [CrossRef]

53. Cainelli, F.; Dzudzor, B.; Lanzafame, M.; Goushchi, A.; Chhem, S.; Vento, S. HIV and SARS-Coronavirus-2 Epidemics: Possible Interactions and Need for Studies, Especially in Africa. Front. Med. 2020, 7, 216. [CrossRef]

54. FAO. FAO Warns of the Impact of COVID-19 on School Feeding in Latin America and the Caribbean; FAO: Rome, Italy, 2020.

55. Jamison, D.T.; Gelband, H.; Horton, S.; Jha, P.K.; Laxminarayan, R.; Mock, C.N.; Nugent, R. Disease Control. Priorities: Improving Health and Reducing Poverty, 3rd ed.; International Bank for Reconstruction and Development/The World Bank: Washington, DC, USA, 2018; Volume 9. [CrossRef]

56. Adebayo, A.A. Implications of "Boko Haram" terrorism on national development in Nigeria: A critical review. Mediterr. J. Soc. Sci. 2014, 5, 480-489. [CrossRef]

57. Eheazu, C.L. The Question of Environmental Illiteracy in Nigeria: An Empirical Analysis and Response. World J. Educ. Res. 2019, 6, 152. [CrossRef]

58. WHO. WHO Supports One Million Malnourished Children in North-East Nigeria; WHO: Geneva, Switzerland, 2019.

59. Childs, C.E.; Calder, P.C.; Miles, E.A. Diet and immune function. Nutrients 2019, 11, 1933. [CrossRef] [PubMed]

60. Ritz, B.W.; Gardner, E.M. Recent Advances in Nutritional Sciences Malnutrition and Energy Restriction Differentially Affect Viral Immunity 1. J. Nutr. 2006, 136, 1141-1144. [CrossRef] [PubMed]

61. Chen, Y.; Peng, H.; Wang, L.; Zhao, Y.; Zeng, L.; Gao, H.; Liu, Y. Infants Born to Mothers with a New Coronavirus (COVID-19). Front. Pediatr. 2020, 8, 104. [CrossRef] [PubMed]

62. Dong, L.; Tian, J.; He, S.; Zhu, C.; Wang, J.; Liu, C.; Yang, J. Possible Vertical Transmission of SARS-CoV-2 From an Infected Mother to Her Newborn. JAMA 2020, 2-4. [CrossRef]

63. UNDP. Upgrading the Slums in Abuja, Nigeria; United Nations Partnerships for SDGs Platform; UNDP: New York, NY, USA, 2015; Available online: https://sustainabledevelopment.un.org/partnership/?p=8993 (accessed on 4 April 2020).

64. DTM. NIGERIA Nigeria-Displacement Report 26 (January 2019). Displacement. Available online: https: //displacement.iom.int/reports/nigeria-displacement-report-26-january-2016 (accessed on 25 April 2020).

65. Holshue, M.L.; DeBolt, C.; Lindquist, S.; Lofy, K.H.; Wiesman, J.; Bruce, H.; Spitters, C.; Ericson, K.; Wilkerson, S.; Tural, A.; et al. First case of 2019 novel coronavirus in the United States. N. Engl. J. Med. 2020, 382, 929-936. [CrossRef]

66. Han, Q.; Lin, Q.; Jin, S.; You, L. Recent insights into 2019-nCoV: A brief but comprehensive review. J. Infect. 2020. [CrossRef]

67. UNDP. UNICEF's Game Plan to End Open Defecation; UNDP: New York, NY, USA, 2020.

68. UN. UN-Water Global Analysis and Assessment of Sanitation and Drinking-Water (GLAAS). Available online: https://www.unwater.org/publication_categories/glaas/page/2/ (accessed on 25 April 2020). 
69. Agboola, G.B.; Adedokun, M.O.; Adeyemo, C.W. Determinant and implications of working past retirement age among adult working population in government parastatals in south west Nigeria. Int. J. Educ. Learn. Dev. 2017, 5, 35-45.

70. Idowu, K.O.; Olanike, K.F. Pensions and pension reform in Nigeria. Pensions 2010, 15, 11-24. [CrossRef]

71. Okubadejo, N.U.; Ozoh, O.B.; Ojo, O.O.; Akinkugbe, A.O.; Odeniyi, I.A.; Adegoke, O.; Bello, B.T.; Agabi, O.P. Prevalence of hypertension and blood pressure profile amongst urban-dwelling adults in Nigeria: A comparative analysis based on recent guideline recommendations. Clin. Hypertens. 2019, 25. [CrossRef]

72. Uloko, A.E.; Musa, B.M.; Ramalan, M.A.; Gezawa, I.D.; Puepet, F.H.; Uloko, A.T.; Borodo, M.M.; Sada, K.B. Prevalence and Risk Factors for Diabetes Mellitus in Nigeria: A Systematic Review and Meta-Analysis. Diabetes Ther. 2018, 9, 1307-1316. [CrossRef] [PubMed]

73. Toniolo, A.; Cassani, G.; Puggioni, A.; Rossi, A.; Colombo, A.; Onodera, T.; Ferrannini, E. The diabetes pandemic and associated infections: Suggestions for clinical microbiology. Rev. Med. Microbiol. 2019, 30, 1-17. [CrossRef] [PubMed]

74. Geerlings, S.E.; Hoepelman, A.I. Immune dysfunction in patients with diabetes mellitus (DM). FEMS Immunol. Med. Microbiol. 1999, 26, 259-265. [CrossRef]

75. Gelston, C.A.L.; Mitchell, B.M. Recent Advances in Immunity and Hypertension. Am. J. Hypertens. 2017, 30, 643-652. [CrossRef] [PubMed]

76. Verity, R.; Okell, L.C.; Dorigatti, I.; Winskill, P.; Whittaker, C.; Imai, N.; Cuomo-Dannenburg, G.; Thompson, H.; Walker, P.G.T.; Fu, H.; et al. Estimates of the severity of coronavirus disease 2019: A model-based analysis. Lancet Infect. Dis. 2020, 1-9. [CrossRef]

77. Pulse Nigeria Coronavirus: Wike, 3 Other Governors Relax Restriction on Religious Gatherings Because of Easter. Available online: https://www.pulse.ng/news/local/coronavirus-wike-3-other-governors-relaxrestriction-on-religious-gatherings-because/yr47hss (accessed on 25 April 2020).

78. Channelstv. COVID-19: Why We Cannot Lockdown North-Northern Governors. Available online: https://www.channelstv.com/2020/04/14/covid-19-why-we-cannot-lockdown-north-northerngovernors/ (accessed on 25 April 2020).

79. Channelstv. COVID-19: Kwara State Announces Total Lockdown. Available online: https://www.channelstv. com/2020/04/09/covid-19-kwara-state-announces-total-lockdown/ (accessed on 25 April 2020).

80. Lu, C.; Liu, X.; Jia, Z. 2019-nCoV transmission through the ocular surface must not be ignored. Lancet 2020. [CrossRef]

81. Addi, R.A.; Benksim, A.; Cherkaoui, M. Easybreath Decathlon Mask: An Efficient Personal Protective Equipment (PPE) against COVID-19 in Africa. J. Clin. Exp. Investig. 2020, 11, em00738. [CrossRef]

82. Zou, L.; Ruan, F.; Huang, M.; Liang, L.; Huang, H.; Hong, Z.; Yu, J.; Song, Y.; Xia, J.; Guo, Q.; et al. Aerosol and Surface Stability of SARS-CoV-2 as Compared with SARS-CoV-1. N. Engl. J. Med. 2020, 382. [CrossRef]

83. European Centre for Disease Prevention. Disinfection of Environments in Healthcare and Non-healthcare Settings Potentially Contaminated with SARS-CoV-2; European Centre for Disease Prevention: Stockholm, Sweeden, 2020.

84. WHO. COVID-19: Operational Guidance for Maintaining Essential Health Services During an Outbreak; WHO: Geneva, Switzerland, 2020.

85. Lagier, J.C.; Colson, P.; Tissot Dupont, H.; Salomon, J.; Doudier, B.; Aubry, C.; Gouriet, F.; Baron, S.; Dudouet, P.; Flores, R.; et al. Testing the repatriated for SARS-Cov2: Should laboratory-based quarantine replace traditional quarantine? Travel Med. Infect. Dis. 2020. [CrossRef]

86. Goyal, K.; Chauhan, P.; Chhikara, K.; Gupta, P.; Singh, M.P. Fear of COVID 2019: First suicidal case in India ! Asian J. Psychiatr. 2020, 49. [CrossRef] [PubMed]

(C) 2020 by the authors. Licensee MDPI, Basel, Switzerland. This article is an open access article distributed under the terms and conditions of the Creative Commons Attribution (CC BY) license (http://creativecommons.org/licenses/by/4.0/). 